\title{
PEMBERDAYAAN PEREMPUAN MELALUI PROGRAM KELUARGA BERENCANA
}

\author{
Oleh: \\ Nandang Mulyana \& Dessy Hasanah S.A.
}

\begin{abstract}
ABSTRAK
Perempuan dalam masyarakat yang patriarkat berada dalam posisi yang kurang menguntung bahkan cenderung berada dalam posisi tidak berdaya. Ketidakberdayaan ini dapat dilihat dari tidak adanya kesempatan dalam mengambil keputusan dalam hidupnya termasuk pengambilan keputusan yang berkaitan dengan dirinya. Ketidakberdayaan ini menjadikan perempuan dalam kondisi yang marginal dalam kehidupan bermasyarakat.

Ketidakberdayaan perempuan ini juga dapat dilihat dalam program KB. Keputusan untuk menggunakn alat kontrasepsi lebih banyak ditentukan oleh pihak laki-laki. Bahkan untuk mejadi akseptor KB juga ditentukan oleh pihak lain khususnya laki-laki. Sementara itu pihak laki-laki sangat sedikit yang menjadi akseptor KB. Hal ini dikarenakan keputusan untuk menjadi akseptor KB ada ditangan laki-laki, sehingga ada keengganan pihak laki-laki menjadi akseptor KB.

Program KB tidak hanya berkaitan dengan menjadi akseptor KB saja tetapi juga banyak program yang bekaitan dengan pemberdayaan khususnya perempuan. Program-program pemberdayaan perempuan dalam program $\mathrm{KB}$ berhubungan dengan kegiatan pemberdayaan yang selanjutnya dikaitkan dengan kehidupan KB. Hasilnya dengan program KB masih sedikit yang dapat memberdayaan perempuan. Hal ini dikarenakan masih kuatnya dominasi laki=laki dalam kehidupan sehari-hari.
\end{abstract}

\section{Kata kunci : Pemberdayaan Perempuan.Program KB}

\section{LATAR BELAKANG}

Manusia dilahirkan mempunyai hak dan kewajiban yang sama. Dalam perjalanan waktu dan dipengaruhi oleh berbagai aspek terjadi perubahan dalam persamaan hak dan kewajiban khususnya antara laki-laki dan perempuan. Perbedaan antara perempuan dan laki-laki ini sangat nyata terlihat pada masyarakat yang menganut budaya patriarki, terlebih pada negara berkembang termasuk Indonesia. Dengan demikian menyebabkan terjadinya ketimpangan dalam kehidupan sosial, ekonomi, politik dan budaya antara laki-laki dengan perempuan. Perempuan menjadi suborddinat yang mendorong terjadinya proses marjinalisasi yang menyebabkan perempuan kehilangan otonomi atas dirinya (Erna Sofyan Sukrie, 2003). Budaya yang dianut dalam masyarakat seperti budaya patriarki akan menentukan perilaku seseorang atau masyarakat (koentjaraningrat, 1974).

Aspek ekonomi dalam keluarga maupun masyarakat menempatkan perempuan dalam kondisi marjinal. Dengan keahlian yang sama perempuan akan mendapatkan diskriminasi baik itu dari segi upah maupun jam kerja. Selain itu juga program-program ekonomi dari pemerintah selalu menempatkan laki-laki dalam prirotas untuk mendapatkan program tersebut. Akibatnya perempuan lebih banyak bergerak di sektor-sektor informal dari pekerjaan. Dengan kondisi ini menyebabkan perempuan tidak mendapatkan penghargaan 
secara ekonomi baik dalam keluarga maupun masyarakat.

Ketimpangan, asimetri, dan subordinat dari perempuan kemudian menjalar juga dalam pengambilan keputusan dalam rumah tangga. Pola asimetris antara suami dan istri terlihat dengan jelas. Suami sebagai kepala keluarga pemilik kekuasaan yang besar dalam kelaurga. Suami mempunyai akses keluar dan pengambil keputusan dalam keluarga. Sedangkan istri sebagai subordinat adalah pengikut yang harus patuh dan terbatas ruang geraknya. Akibat lebih jauhnya perempuan tidak mempunyai kekuasaan baik dalam keluarganya maupun dalam masyarakat. Dengan demikian perempuan tidak berdaya baik untuk memperjuangkan hak-haknya maupun untuk berkarya dalam masyarakat.

Ketidakberdayaan perempuan dalam keluarga terlihat dari sulitnya perempuan untuk melakukan kegiatan diluar keluarganya. Kondisi ini diperparah dengan budaya yang berkembang seperti di masyarakat Jawa dan Sunda dengan slogan "banyak anak banyak rejeki”. Slogan ini disatu sisi menempatkan keluarga untuk lebih mudah mengerjakan pekerjaan dalam rangka menghidupi keluarga. Peran ayah akan terbantu dengan banyaknya anak, karena anak merupakan "asset" tenaga kerja. Di sisi lain dengan anak yang banyak peran ibu menjadi lebih berat, karena harus merawat dan mendidik anak-anaknya. Dengan banyaknya anak yang terlahir dalam suatu keluarga, perempuan akan lebih banyak menghabiskan waktunya di dalam keluarga dengan merawat dan mengasih anak-anaknya. Semnetara itu laki-laki lebih banyak menghabiskan waktunya di luar keluarga.

Berdasarkan latar belakang tersebut perlu adanya kegiatan yang dapat menekan ketimpangan, asimetris, dan subordinatnya perempuan baik dalam keluarga maupun masyarakat. Program keluarga berencana merupakan salah satu program yang diharapkan dapat meningkatkan keberdayaan perempuan. Pembatasan kelahiran anak dalam keluarga diharapkan perempuan dapat berkiprah baik dalam keluarga maupun masyarakat. Selain itu pembatasan kelahiran anak dalam keluarga juga akan lebih menjamin masa depan anak itu sendiri. Diskriminasi perempuan dalam keluarga akan terkikis jika jumlah anak dalam keluarga terbatas. Dengan kondisi ini anak perempuan mempunyai kesempatan yang sama dengan anak perempuan

\section{TINJAUAN KONSEPTUAL}

\section{a. Pembedayaan Perempuan}

Pemberdayaan merupakan sebuah kata yang sering kali mempunyai arti yang kurang baik. Hal ini disebabkan karena kata pemberdayaan menunjukkan bahwa ada pihakpihak tertentu yang perlu ditolong karena ketidakmampuannya. Kata pemberdayaan merupakan terjemahan dari kata "empowerment" yang lebih menekankan pada "mengambil alih kekuasaan" (Ratna Saptari, 1997). Jadi pengertian pemberdayaan seolah mempunyai konotasi negatif, yaitu mengambil alih kekausaan yang dilakukan oleh satu pihak terhadap pihak lain yang dirasakan mempunyai kekuasaan yang lebih banyak. Pengertian tersebut sejalan dengan yang dikemukakan oleh Tan yang melihat pemberdayaan sebagai suatu proses menantang hubungan kekuasaan yang ada dan memperoleh penguasaan yang lebih besar atas sumber-sumber kekuasaan. Dengan demikian pemberdayaan merupakan suatu redistribusi kekuasaan yang ada, dalam kasus di sini kekuasaan yang ada dalam keluarga.

$\begin{array}{ccc}\text { Ife } & (1995) & \text { mendefinisikan } \\ \text { pemberdayaan } & \text { sebagai } & \text { upaya untuk }\end{array}$
memberikan otonomi, wewenang, dan kepercayaan kepada setiap indiividu dalam suatu organisasi, serta mendorong mereka untuk kreatif agar dapat menyelesaikan tugasnya sebaik mungkin. Berdasarakan definisi dari Ife tersebut terlihat bahwa setiap individu yang ada dalam suatu organisasi, dalam kasus ini keluarga, harus diberi otonomi, weweang, dan keperayaan yang dapat mendorong individu tersebut berkreasi menyelesaikan permasalahan yang dihadapi baik masalah individu maupun organisasi. Kemudian Swift dan Levin, 1987) mendefinisikan pemberdayaan sebagai suatu 
usaha pengalokasian kembali kekuasaan melalui perubahan struktur sosial. Pendapat Swift dan Levin ini lebih menekankan perlu adanya perubahan alam struktur organisasi sehingga akan terbagi kekuasaan secara adil.

Definisi lainnya mengenai
prmberdayaan adalah kemampuan orang, khususnya kelompok rentan dan lemah untuk (1), mempunyai akses terhadap sumbersumber produktif yang dapat meningkatkan kesejahteraannya, (2), berpatisipasi dalam proses pengambilan keputusan yang dapat mempengaruhi mereka. Definisi tersebut memperlihatkan bahwa pemberdayaan menunjukkan ada pihak yang dianggap lemah dalam mengakses sumber-sumber yang dibutuhkan serta perlu adanya partisipasi dalam pengambilan keputusan yang berhubungan dengan kebutuhan mereka. Jadi pemberdayaan dapat didefinisikan sebagai pendistribusian kekuasaan terhadap individu sehingga memperoleh akses terhadap sumbersumber daya dengan perubahan struktur sosial yang ada sehingga individu tersebut dapat berpartisipasi dalam pengembilan kekuptusan baik untuk dirinya maupun masyarakat.

Berdasarkan definisi-definisi mengenai pemberdayaan yang dikemukakan oleh para ahli terlihat bahwa pemberdayaan dapat dilihat dari tiga sisi (Sumodiningrat, dalam Gunawan, 2002) yaitu, pertama pemberdayaan menciptakan suasana atau iklim yang memungkinkan potensi individu dan masyarakat berkembang. Sisi ini memperlihatkan bahwa setiap individu maupun masyarakat mempunyai potensi yang dapat dikembangkan dan digunakan untuk mengatasi permasalahan maupun meningkatkan kesejahteraan individu maupun masyarakat.

Kedua, pemberdayaan adalah untuk memperkuat potensi atau daya yang dimiliki individu maupun masyarakat. Sisi kedua ini lebih ditekankan pada langkah-langkah yang harus dilakukan dalam pemanfaatan potensi yang dimiliki indiivdu maupun masyarakat. Penguatan potensi yang dimiliki ini tidak hanya penguatan pada potensi yang dimiliki oleh individu maupun masyarakat saja, tetapi juga penguatan-penguatan terhadap institusiinstitusi yang ada dalam masyarakat. Penguatan potensi individu maupun masyarakat juga berhubungan dengan partisipasi yang diberikan oleh individu maupun masyarakat dalam menentukan dan mengambil keputusan yang menyangkut dirinya sendiri maupun masyarakatnya.

Ketiga, pemberdayaan merupakan perlindungan. Pemberdayaan harus diarahkan untuk memperkuat pihak-pihak atau individuindividu yang dianggap lemah, sehingga menjadi lebih kuat. Pemberdayaan harus memperlihatkan adanya pemihakan terhadap yang lemah tanpa mengisolasinya. Melindungi dalam pemberdayaan juga harus mengupayakan dan mencegah terjadinya persaingan yang tidak seimbang serta menghindarkan terjadinya eksploitasi dari pihak atau individu yang kuat terhadap yang lemah. Dengan demikian pemberdayaan harus menekankan pada kerja keras individu maupun masyarakat sehingga dapat mengatasi masalah yang dihadapi maupun mengembangkan potensi yang ada.

Pemberdayaan dapat dilakukan terhadap individu, kelompok maupun masyarakat. Pemberdayaan yang menekankan pada kelompok tertentu, dalam hal ini perempuan, dapat dilakukan. Pemberdayaan perempuan menekankan pada upaya untuk dapat mengakses sumber daya serta dapat mengambil keputusan yang berhubungan dengan dirinya maupun keluarga. Tujuan dari pemberdayaan perempuan mengacu pada pertama, untuk menantang ideology patriarki, yaitu adanya dominasi laki-laki atas perempuan khususnya dalam keluarga. Kedua, mengubah struktur dan institusi yang dapat memperkuat dan melestarikan diskriminasi gender dan ketidaksamaan sosial, khususnya dalam keluarga. Ketiga, member kemungkinan bagi perempuan untuk dapat mengakses kepada dan penguasaan terhadap sumbersumber material ataupun informasi (Dini Anitasari Sabaniah, 2009).

Pemberdayaan juga dapat dilakukan terhadap perempuan. Keberhasilan pemberdayaan perempuan tentunya tidak 
dapat ditentukan secara sepihak. Ada indikator-indikator tertentu yang harus dipenuhi untuk melihat keberhasilan pemberdayaan perempuan. Indikator-indikator pemberdayaan perempuan dikembangkan oleh Schuler, Hashemi, dan Riley (dalam Girvan, 2004) yaitu :

1. Kebebasan mobilitas, yaitu kemampuan individu dalam hal ini perempuan untuk pergi ke luar rumah atau wilayah tempat tinggalnya. Tingkat mobilitas dianggap tinggi jika individu atau perempuan mampu untuk pergi sendirian.

2. Kemampuan membeli komoditas "kecil" yaitu kemampuan individu atau perempuan untuk membeli barang-barang kebutuhan keluarga sehari-hari dan kebutuhan seharihari untuk dirinya. Individu dianggap mampu melakukan kegiatan ini terutama jika individu tersebut dapat membuat keputusan sendiri tanpa meminta ijin pasangannya, terlebih lagi jika perempuan tersebut dapat membeli komoditas tersebut dengan menggunakan uangnya sendiri.

3. Kemampuan membeli komoditas "besar" yaitu kemampuan individu atau perempuan untuk membeli barang-barang yang bersifat sekunder atau tersier, tanpa meminta ijin pasangannya dan lebih tinggi lagi jika menggunakan uang sendiri dalam membeli komoditas tersebut.

4. Terlibat dalam pembuatan keputusankeputusan rumah tangga, yaitu mampu untuk membuat keputusan sendiri maupun bersama suami mengenai keputusankeputusan keluarga.

5. Kebebasan relatif dari dominasi keluarga.

6. Kesadaran hukum dan politik, contohnya dapat menyebutkan para peminpin masyarakatnya, mengetahui pentingnya mempunyai surat nikah dan hukum waris.

7. Keterlibatan dalam kegiatan politik praktis

8. Jaminan ekonomi dan kontribusi terhadap keluarga seperti memiliki tempat tinggal, asset produktif, tabungan.

\section{b. Pemberdayaan Perempuan melalui Program Keluarga Berencana}

Keberhasilan program Keluarga Berencana (KB) sangat tergantung kepada partisipasi masyarakat. Tingkat partisipasi masyarakat dalam program Keluarga Berencana (KB) yang tinggi diharapkan tujuan dari program Keluarga Berencana (KB) dapat tercapai. Salah satu indikator keberhasilan dari program Keluarga Berencana (KB) adalah menurunnya tingkat pertumbuhan penduduk. Partisipasi dan pemberdayaan perempuan dalam program Keluarga Berencana (KB) merupakan strategi yang potensial dalam meningkatkan akses perempuan serta transformasi budaya (Hikmat, 2004).

Partisipasi merupakan komponen penting dalam meningkatkan kemandirian dan pemberdayaan (Craig dan May, dalam Hikmat, 2004). Partisipasi merupakan pengambilan bagian dalam suatu tahap atau lebih dari suatu proses dalam hal ini pemberdayaan perempuan yang berhubungan dengan program Keluarga Berencana (KB) (Hoofsteede, dalam Khairuddin 2000). Sedangkan prinsip dari partisipasi adalah peran serta masyarakat, dalam hal ini perempuan, secara langsung, dan hanya mungkin dicapai jika masyarakat ikut ambil bagian sejak dari awal dan perumusan hasil (Abe, 2005). Selanjutnya Abe mengemukakan melibatkan perempuan dalam pemberdayaan dalam program Keluarga Berencana akan membawa dampak yaitu (1) terhindarkan perempuan dari peluang terjadinya manipulasi. Partisipasi perempuan akan memperjelas apa yang sebebanrnya dikehendaki oleh perempuan itu sendiri. (2), memberikan nilai tambah pada legitimasi rumusan masalah karena semakin banyak jumlah yang terlibat akan semakin baik. (3), meningkatkan kesadaran dan ketrampilan politik perempuan.

Partisipasi perempuan dalam program Keluarga Berencana ini tentunya harus didukung oleh anggota keluarga yang lain. Partisipasi perempuan dalam program Keluarga Berencana (KB) bukan semata-mata partisipasi yang terpaksa karena kondisi perempuan dalam keluarga yang menjadi 
subordinat dan terjadi ketimpangan dalam kekuasaan. Partisipasi perempuan dalam program Keluarga Berencana justru harus menjadi pendorong untuk meningkatkan keberdayaan perempuan dalam mengambil keputusan baik itu untuk dirinya maupun untuk keluaganya. Oleh sebab itu partisipasi perempuan dalam program Keluarga Berencana mempunyai dua hal yang berhubungan dengan pemberdayaan perempuan yaitu pertama, perempuan dalam hal ini istri harus lembih berdaya setelah terlibat dalam program Keluarga Berencana. Partisispasi dan pemilihan kontrasepsi oleh perempuan harus merupakan keputusan bersama antara suami-istri. Hasil dari program Keluarga Berencana yang melibatkan perempuan diharapkan tingkat kelahiran anak dalam keluarga berkurang. Ini berarti perempuan akan terkurangi beban mengandung, melahirkan dan merawat anakanak dalam jangak waktu yang lama. Dengan demikian banyak waktu luang yang dapat dimanfaatkan oleh perempuan untuk berkarya dalam masyarakat.

Kedua, partisipasi perempuan dalam program Keluarga Berencana juga akan menningkatkan keberdayaan anak perempuan dalam suatu keluarga. Jumlah anak yang terbatas menjadikan setiap anak baik perempuan maupun laki-laki memperoleh kesempatan yang sama besar untuk mendapatkan perawatan dan pendidikan. Hal ini terjadi karena anak-anak yang lahir dalam suatu keluarga tidak banya.

\section{HASIL KAJIAN}

\section{a. Partisipasi Perempuan dalam Program Keluarga Berencana}

Pertumbuhan penduduk di Jawa Barat yang sangat pesat perlu ada program untuk memperlambatnya. Program Keluarga Berencana merupakan program yang bertujuan untuk mengupayakan peningkatan kepedulian dan peran serta masyarakat melalui pendewasaan usia perkawinan, pengaturan kelahiran, pembinaan keluarga, peningkatan kesejahteraan keluarga untuk mewujudkan keluarga kecil bahagian dan sejahtera
(BKKBN, 2008). Penekanan dari program Keluarga Berencana ini adalah adanya peran serta dari masyarakat baik itu laki-laki maupun perempuan.

Di Propinsi Jawa Barat tahuan 2009 tercatat ada 8.842.229 pasangan usia subur (PUS) (BKKBN Jawa Barat 2009). Jumlah jika tidak dikendalikan dengan program Keluarga Berencana akan mendongkrak penduduk Propinsi Jawa Barat pada tahun 2010 sebanyak 45.512.637 jiwa. Hasil sensus 2010 penduduk Propinsi Jawa Barat berjumlah 43.021.826 jiwa. Jadi dengan demikian ada selisih yang cukup besar jumlah penduduk menurut perkiraan jika pasangan usia subur tidak dikendalikan oleh program Keluarga Berencana (KB) dengan hasil sensus. Kondisi ini menggambarkan bahwa program Keluarga Berencana di Propinsi Jawa Barat cukup berhasil untuk menekan kelahiran.

Keberhasilan program Keluarga Berencana di Propinsi Jawa Barat dalam menekan angka kelahiran ternyata belum sejalan dengan pemberdayaan perempuan dalam program Keluarga Berencana (KB). Hal ini dapat dilihat dari pilihan alat kontrasepsi yang banyak digunakan oleh akseptor KB yang masih didominasi oleh alat kontrasepsi yang bersifat hormonal (seperti PIL, suntik, dan implant). Demikian juga alat kontrasepsi nonhormaonal (seperti IUD, MOW, MOP, dan kondom) masih didominasi peserta perempuan. Penggunaan alat kontrasepsi tersebut menunjukkan bahwa pengguna alat kontrasepsi tersebut didominasi oleh perempuan. Padahal penggunaan alat kontrasepsi seharusnya menjadi tanggung jawab bersama antara suami dan istri. Dengan demikian menjadi akseptor keluarga berencana bukan saja menjadi tanggung jawab perempuan tetapi juga menjadi tanggung jawab laki-laki.

Berdasarkan data BKKBN Propinsi Jawa Barat tahun 2011 terlihat bahwa partisipasi perempuan dalam program Keluarga Berencana sangat tinggi. Tabel dibawah ini memperlihatkan partisipasi perempuan dalam program Keluarga Berencana sebagai berikut : 
Tabel 1 :

Peserta Aktif KB di Propinsi Jawa Barat

\begin{tabular}{|l|l|l|}
\hline No. & $\begin{array}{l}\text { Metode } \\
\text { Kontrasepsi }\end{array}$ & $\begin{array}{l}\text { Jumlah Peserta } \\
\text { Aktif }\end{array}$ \\
\hline 1 & IUD & 822.574 \\
\hline 2 & MOW & 170.534 \\
\hline 3 & MOP & 64.891 \\
\hline 4 & Kondom & 91.912 \\
\hline 5 & Impalnt & 320.924 \\
\hline 6 & Suntikan & 3.595 .998 \\
\hline 7 & Pil & 1.947 .880 \\
\hline Jumlah Peserta Aktif & 7.014 .713 \\
\hline $\begin{array}{l}\text { Jumlah Pasangan Usia } \\
\text { Subur }\end{array}$ & 9.140 .776 \\
\hline
\end{tabular}

Sumber : BKKBN Propinsi Jawa Barat 2011

Partisipasi pasangan usia subur (PUS) di Propinsi Jawa Barat yang menjadi peserta aktif dalam program Keluarga Berencana (KB) berdasarkan data tabel 3 terlihat cukup tinggi yang mencapai $76 \%$. Ini menandakan bahwa program Keluarga Berencana di Propinsi Jawa Barat berhasil menarik minat pasangan usia subur untuk berpartisipasi. Akan tetapi jika ditelaah lebih mendalam data dari tabel 3 tersebut terlihat bahwa partisipasi pasangan usia subur (PUS) dalam program Keluarga Berencana masih didominasi oleh perempuan. Partisipasi perempuan mencapai lebih dari 95 $\%$. Ini menunjukkan bahwa partisipasi perempuan dalam program Keluarga Berencana di Propinsi Jawa Barat sangat tinggi.

Partisispasi perempuan dalam program Keluarga Berencana yang tinggi ini dapat dilihat dalam dua sisi. Pertama, partrisipasi perempuan dalam program Keluarga Berencana menunjukkan bahwa kesadaran perempuan sudah tinggi. Perempuan sadar akan kesehatan reproduksinya serta mampu untuk membuat perencanaan untuk dirinya maupun keluarganya. Perempuan yang termasuk kepada golongan ini adalah perempuan yang mempunyai tingkat pendidikan yang sudah tinggi. Mereka adalah perempuan yang mempunyai tingkat pendidikan minimal SMA. Selain itu juga perempuan yang bekerja pada sektor formal. Mereka beranggapan bahwa dengan bekerja mereka tidak mempunyai waktu yang banyak untuk mengurus anak, sehingga mereka lebih senang dengan anak yang sedikit. Kemudian pemilihan untuk menjadi peserta Keluarga Berencana (KB) juga atas keputusan bersama dengan suaminya. Bahkan pemilihan alat kontrasepsi lebih banyak ditentukan oleh istri. Kedua, partisipasi perempuan dalam program Keluarga Berencana justru menunjukkan bahwa perempuan masih belum mampu untuk keluar dari dominasi laki-laki. Perempuan yang termasuk pada golongan ini adalah perempuan yang memiliki tingkat pendidikan pada umumnya rendah serta tidak bekerja, sehingga secara ekonomi tergantung kepada suaminya. Perempuan menjadi peserta Keluarga Berencana (KB) lebih banyak ditentukan oleh suaminya (laki-laki). Partisipasi perempuan dalam program Keluarga Berencana hanya sebagai obyek saja tanpa mampu untuk bisa menolak atau mengikuti sesuai dengan kehendaknya. Partisipasi perempuan dalam program Keluarga Berencana lebih banyak karena adanya dorongan dari anggota keluarga yang lain. Selain itu juga partsisipasi perempuan hanya karena untuk menunda sementara kelahiran selanjutnya. Kondisi ini diperkuat dengan data lainnya dari BKKBN Propinsi Jawa Barat tahun 2011 yang memperlihatkan bahwa partisipasi perempuan yang berasal dari keluarga prasejahtera dan sejahtera I maupun keluarga mampu lebih banyak dibandingkan dengan keluarga mampu. Keluarga prasejahetara dan sejahtera I yang berpartisispasi dalam program Keluarga Berencana mencapai 75,5\% (3.277.104 yang menjadi peserta dari 4.337.760 keluarga).

\section{b. Partisipasi Laki-laki dalam Program Kelurga Berencana}

Berbeda dengan partisipasi perempuan, partisipasi laki-laki dalam program Keluarga Berencana (KB) masih sangat rendah. Data BKKBN Propinsi Jawa Barat tahun 2011 memperlihatkan bahwa partisipasi laki-laki dalam program Keluarga Berencana di Propinsi Jawa Barat hanya mencapai 2,24\% dari peserta aktif (156.803 dari 7.014.713). 
Rendahnya partisipasi laki-laki dalam program Keluarga Berencana (KB) merata di semua kabupaten/kota yang ada di Propinsi Jawa Barat. Tabel 4 dan 5 memperlihatkan partisipasi laki-laki dalam program Keluarga Berencana berdasarkan alat kontrasepsi yang digunakan di lima kabupaten/kota tertinggi sebagai berikut :

Tabel 2

DAFTAR PESERTA KB AKTIF MOP/VASEKTOMI KABUPATEN/KOTA LIMA TERBESAR DI JAWA BARAT

\begin{tabular}{|c|c|c|c|}
\hline No & Kabupaen/Kota & Persentasi & Keterangan \\
\hline 1 & Kota Banjar & $3,47 \%$ & \\
\hline 2 & $\begin{array}{c}\text { Kabupaten } \\
\text { Majalengka }\end{array}$ & $1,71 \%$ & \\
\hline 3 & $\begin{array}{c}\text { Kabupaten } \\
\text { Sukabumi }\end{array}$ & $1,71 \%$ & \\
\hline 4 & $\begin{array}{c}\text { Kabupaten } \\
\text { Cianjur }\end{array}$ & $1,59 \%$ & \\
\hline 5 & $\begin{array}{c}\text { Kabupaten } \\
\text { Subang }\end{array}$ & $1,56 \%$ & \\
\hline
\end{tabular}

Sumber : BKKBN Propinsi Jawa Barat

Tabel 3

DAFTAR PESERTA KB AKTIF KONDOM DI LIMA KOTA/KABUPATEN TERBESAR DI JAWA BARAT

\begin{tabular}{|c|c|c|c|}
\hline No & Kabupaten/Kota & Persentase & Keterangan \\
\hline 1 & Kota Bekasi & $2,98 \%$ & \\
\hline 2 & Kota Bogor & $2,41 \%$ & \\
\hline 3 & Kota Cirebon & $2,20 \%$ & \\
\hline 4 & Kota Banjar & $2,12 \%$ & \\
\hline 5 & Kota Depok & $1,66 \%$ & \\
\hline
\end{tabular}

Sumber : BKKBN Provinsi Jabar

Data tabel 4 dan 5 memperlihatkan bahwa partisipasi laki-laki dalam program Keluarga Berencana (KB) di Propinsi Jawa Barat masih lebih rendah dibandingkan dengan rata-rata nasional yang mencapai $3,2 \%$. Permasalahan yang berhubungan dengan masih rendahnya partisipasi laki-laki dalam program Keluarga Berencana dapat dilihatdari tiga hal. Pertama, pengetahuan laki-laki mengenai Keluarga Berencana (KB) masih rendah. Rendahnya pengetahuan laki-laki tersebut dapat dilihat masih suburnya anggapan yang membedakan antara peran lakilaki dengan perempuan. Perempuan secara kodrati yang harus hamil, maka menjadi tanggung jawab perempuan pula untuk mengatur kehamilan dan kelahiran. Lai-laki tidak bertanggung jawab terhadap kesehatan reproduksi perempuan. Rendahnya pengetahuan laki-laki mengenai Keluarga Berencana (KB) tidak disebabkan karena pendidikan. Hal ini terlihat bahwa rendahnya partisipasi laki-laki yang menjadi peserta Keluarga Berencana (KB) terjadi di kota maupun desa dengan tingkat pendidikan yang bervariasi. Demikian juga dengan pekerjaan tidak berpengaruh secara signifikan, karena pada semua pekerjaan tidak menunjukkan adanya perbedaan yang berbeda secara mencolok.

Kedua, masih terbatasnya alat kontrasepsi bagi laki-laki. Sampai saat ini di Indonesia hanya ada dua alat kontrasepsi modern yaitu MOP dan kondom. Sedangkan konrasepsi secara tradisional dengan senggama terputus dan pantang berkala. Terbatasnya alat kontrasepsi modern untuk laki-laki menyebabkan banyak laki-laki yang enggan untuk berpatisipasi dalam program Keluarga Berencana. Demikian juga dengan kontrasepsi tradisional juga dirasakan tidak mudah dan dianggap mengganggu kenyamanan. Selain terbatasnya kontrasepsi bagi laki-laki juga masih ada anggapan menggunakan kontrasepsi baik yang modern khususnya kondom maupun yang tradisional dirasakan oleh lak-laki membuat hubungan dengan istri kurang nyaman dan membuat ribet. Akibatnya laki-laki memilih lebih baik tidak menggunakan kontrasepsi.

Ketiga, masih kuatnya pengaruh budaya patriarki dalam masyarakat yang mendudukkan laki-laki sebagai pemimpin. Kekuasaan laki-laki sebagai kepala keluarga menyebabkan laki-laki bebas untuk menentukan arah dan tujuan untuk dirinya dan keluarganya. Perempuan sebagai bagian dari keluarga harus tunduk kepada laki-laki. Akibatnya dalam berKB juga laki-laki menunjuk perempuan untuk berpartisipasi dalam program Keluarga Berencana dibanrinngkan dengan dirinya. 


\section{c. Tingkat Kelahiran dan Kematian Ibu dan Bayi Berhubungan dengan Pemberdayaan Perempuan}

Keberdayaan perempuan tidak hanya dapat dilihat dari partisipasi perempuan dan laki-laki dalam program Keluarga Berencana, tetapu juga dapat dilihat dari tingkat kelahiran dan kematian bayi dan balita serta ibu. Hasil sensus 2010 tingkat kelahiran di Propinsi Jawa Barat sebesar 2,6. Angka ini masih lebih tinggi dibandingkan dengan angka nasional yang 2,25. Sedangkan angka kematian bayi dan balita di Propinsi Jawa Barat juga menunjukkan angka yang masih tinggi. Bisnis Indonesia edisi 11 Oktober 2012 memberikan data bahwa di Propinsi Jawa Barat pada tahun 2010 ada 794 kematian ibu dan 4.987 kasus kematian bayi dan balita. Data ini memperlihatkan bahwa dalam satu hari ada dua sampai tiga ibu meninggal akibat melahirkan dan 9 sampai 10 bayi yang meninggal pascadilahirkan. Angka menunjukkan bahwa kematian ibu dan bayi di Propinsi Jawa Barat salah satu yang tertinggi di Indonesia.

Masih tingginya angka kematian baik ibu maupun bayi disebabkan karena beberapa hal yaitu pertama, masih rendahnya pengetahuan masyarakat khususnya perempuan mengenai sebelum dan setelah kehamilan. Angka kematian ibu dan bayi ini juga menunjukkan belum berdayanya perempuan dalam menjaga kesehatan sebelum dan sesudah kehamilan. Perempuan jarang untuk memeriksakan kehamilannya serta kurang memakan makanan yang sesuai dengan kebutuhan sewaktu hamil. Kondisi inipun terjadi sewaktu bayi lahir, pemeriksaan dan pemberian ASI bagi bayi tidak disertai dengan pengetahuannya. Makanan tambahanpun diberikan tidak sesuai dengan usia dari bayi tersebut, bahkan kadangkala makanan untuk orang tuapun diberikan kepada bayi.

Kedua, kurang pedulinya laki-laki terhadap kesehatan perempuan dan bayi. Lakilaki seringkali tidak peduli dengan kehamilan dan kelahiran. Laki-laki sering beranggapan bahwa kehamilan adalah urusan perempuan. Ketidakpedulian laki-laki juga dapat dilihat dari jarangnya laki-laki untuk ikut serta dalam pemeriksaan kehamilan dan bayi. Akibatnya pengetahuan laki-laki mengenai kehamilan dan bayi rendah sehingga tidak peduli. Ketiga, budaya yang masih tradisional yang kurang mendukung terhadap perempuan hamil dan bayi. Prosesi budaya dalam menyambut kehamilan maupun kelahiran seringkali mengabaikan keselamatan dan kesehatan dari ibu maupun bayi.

Tingginya angka kematian perlu adanya penanganan yang tepat sehingga dapat menekan angka kematian ibu dan bayi serta menekan angka kelahiran. Penanganan itu adalah peningkatan partisipasi dalam program Keluarga Berencana (KB), dan Peningkatan Usia Perkawinan (PUP) (Euis Nurmala, 2011). Peningkatan partisipasi dalam program Keluarga Berencana (KB) dengan penekanan pada pertambahan pengetahuan masyarakat khususnya perempuan akan pentingnya program Keluarga Berencana (KB). Sosialisasi harus lebih digencarkan lagi, karena sampai saat ini di Propinsi Jawa Barat masih ada 2.126.063 pasangan usia subur yang belum menjadi peserta aktif keluarga Berencana (KB). Masih banyaknya pasangan usia subur yang belum menjadi peserta aktif keluarga berencana (KB) menjadi ancaman bagi kependudukan di Propinsi Jawa Barat.

Tingginya pasangan usia subur yang belum menjadi peserta keluarga berencana (KB) disebabkan beberapa hal, pertama, masih rendahnya pengetahuan dari pasangan usia subur tersebut mengenai keluarga berencana (KB). Hal ini dapat dilihat dari masih tingginya angka kelahiran di Propinsi Jawa Barat yang melebihi angka kelahiran nasional. Selain itu juga masih tingginya angka kematian ibu dan bayi pascakelahiran. Indicator ini menunjukkan bahwa pengerahuan dari pasangan usia subur tersebut masih rendah mengenai keluarga berencana, khususnya perempuan karena perempuan berhubungan langsung dengan kehamilan dan kelahiran.

Kedua, masih dominannya pengaruh laki-laki, dalam hal ini suami dalam keluarga. Perempuan tidak berdaya jika laki-laki yang menjadi suaminya melarangnya untuk menjadi 
peserta aktif keluarga berencana. Sementara disisi lain laki-laki tidak mau menjadi peserta aktif dalam keluarga berencana. Pengetahuan dan dominasi laki-laki ini yang menyebabkan masih adanya pasangan usia subur yang belum menjadi peserta aktif keluarga berencana.

Usia perkawinan pertama masyarakat Propinsi Jawa Barat rata-rata berada pada kisaran 18,7 tahun. Angka ini menunjukkan bahwa masyarakat Propinsi Jawa Barat menikah untuk pertama kali pada usia yang masih muda. Selain menikah pada usia muda juga tidak menunda kehamilan pertama. Hasil penelitian dari Ikatan Sosiologi Indonesia Jawa Barat menujukkan bahwa usia menikah pertama di Propinsi Jawa Barat adalah yang terendah secara usia. Demikian juga kelahiran anak pertama menujukkan bahwa 12,6\% melahirkan pada usia antara 15-19 tahun. Menikah muda tanpa menunda kelahian anak pertama sangat rentan terhadap kesehatan ibu dan bayi. Dengan demikian perlu adanya sosialisasi mengenai usia ideal untuk menikah yang berada pada kisaran 20 tahun untuk perempuan dan 25 tahun bagi laki-laki. Pada usia tersebut dari segi kesehatan sudah matang demikian juga dari segi psikis dalam menghadapi rumah tangga.

Alasan menikah muda adalah pertama, bahwa menikah di usia muda akan menghindarkan dirinya dari perbuatanperbuatan yang bertentangan dengan norma agama maupun susila. Dengan berpacaran dikhawatirkan terjerumus pada perbuatan asusila yang melanggar norma agama dan kemasyarakatan. Kedua, menikah itu terlihat menyenangkan. Ada teman untuk berbagi kebahagiaan dan kesulitan. Menikah pada usia muda juga sangat rentan terjadinya perceraian. Hal ini disebabkan karena belum matangnya psikis masing-masing pasangan serta belum mapannya ekonomi pasangan tersebut. Perceraian sangat mempengaruhi kondisi perempuan terlebih jika sudah mempunyai anak. Pada umumnya perempuan yang menikah pada usia muda tidak bekerja dan secara ekonomi sangat tergantung kepada suaminya. Apabila bercerai maka secara ekonomi perempuan tersebut akan berada pada posisi yang tidak menguntungkan. Angka perceraian di Propinsi Jawa Barat termasuk tinggi terutama di Kabupaten Indramayu, Purwakarta, Garut, Cianjur, Majalengka, dan Sukabumi. Hasil penelitian di Amerika Serikat memperlihatkan bahwa laki-laki yang telah bercerai cenderung untuk mempunyai kehidupan yang lebih mapan. Sedangkan perempuan yang bercerai apalagi memiliki anak cenderung tingkah kesejahteraannya menurun. Hal ini dapat dimaklumi karena dengan betcerai seorang laki-laki lebih bebas untuk kreatif dalam kehidupannya. Sedangkan perempuan dengan status dan anak yang dimilikinya menjadi lebih menutup diri, sehingga pergaulannya semakin terbatas.

\section{d. Partisipasi Perempuan dalam Program Pemberdayaan Perempuan di Propinsi Jawa Barat berkaitan dengan Keluarga Berencana}

Partisipasi perempuan dalam program pemberdayaan pada umumnya diarahkan untuk meningkatkan kesejahteraan keluarga. Kegiatan pemberdayaan perempuan yang berhubungan dengan keluarga berencana ini meliputi pembinaan ketahanan keluarga, dan pembinaan kesejahteraan keluarga. Kegiatan pembinaan ketahanan keluarga terbagi atas Bina Keluarga Balita (BKB), Bina Keluarga Remaja (BKR), dan Bina Keluarga Lansia (BKL). Keluarga yang terlibat dalam BKB untuk Propinsi Jawa Barat sudah mencapai 840.203 keluarga (BKKBN Propinsi Jawa Barat). Sedangkan keluarga yang terlibat dalam BKR sejumlah 606.271 keluarga, dan keluarga yang terlibat dalam BKL berjumlah 417.643 keluarga.

Jika dilihat dari partisipasi dalam pertemuan yang diadakan oleh poktan BKB rata-rata mencapai $89,95 \%$ dari semua peserta aktif. Angka cukup tinggi walaupun masih ada kabupaten/kota yang tingkat partisipasi dalam BKB ini masih rendah. Kabupaten/kota yang mempunyai persentase kehadiran keluarga khususnya perempuan dalam kegiatan BKB adalah Kabupaten Cirebon $(43,1 \%)$ dan Kota Bekasi (45,0\%). Sedangkan Kabupaten/kota yang tinggi persentase partisipasi keluarga 
dalam BKB adalah Kota Cirebon (142,2\%), Kabupaten Bandung (127,9\%), dan Kota Banjar (126,2).

Sementara partisipasi keluarga dalam BKR yang tertinggi ada di Kota Banjar (158,3\%), Kabupaten Bandung (156,^\%), dan Kota Cirebon (124,2\%). Sedangakn partisipasi yang rendah ada di Kabupaten Bandung Barat $(31,2 \%)$ dan Kota Bekasi (35,8\%). Sementara itu partisipasi di Propinsi Jawa Barat sebesar $82,5 \%$.

Partisipasi dalam BKL paling tinggi di Kabupaten Subang (96,4\%) dan Kota Sukabumi $(86,8 \%)$. Sementara Kabupaten Cianjur $(45,0 \%)$ dan Kabupaten Tasikmalaya (472,\%) merupakan daerah yang rendah partispasinya dalan BKL. Untuk Propinsi Jawa Barat tercatat sebesar67,9\%.

Berdasarkan data terebut terlihat bahwa partisipasi keluarga dalam BKB, BKR, dan BKL di Propinsi Jawa Barat terlihat tinggi karena rata-rata sudah diatas $70 \%$. Jika ditelaah lebih mendalam ada dua hal yang terjadi dengan partisipasi ini, pertama kesadaran yang sudah tinggi dari keluarga dan perempuan dalam pembinaan ketahanan keluarga. Hal ini disebabkan karena sosialisasi yang telah dilakukan dapat diterima dengan baik oleh masyarakat. Kedua dapat juga pertisipasi ini tinggi karena adanya keterpaksaan yang diterima oleh keluarga khususnya oleh perempuan. Jika hal ini terjadi maka pertemuan alam kegiatan pembinaan ketahanan keluarga ini akan sia-sia. Hal ini disebabkan partisipasi ini bukan merupakan keputusan yang diambil secara mandiri baik itu oleh perempua maupunkeluarga secara keseluruhan.

Sedangkan program Pembinaan Kesejahteraan Keluarga diwakili oleh kegiatan UPPKS. Anggoat UPPKS di Propinsi Jawa Barat pada bulan Desember 2011 mencapai 277.975 keluarga. Berdasarkan data tersebut tercatat anggota UPPKS yang menjadi peserta KB sebanyak 132.257 atau $79,18 \%$ dari jumlah PUS sebanyak 167.036 peserta KB. Sedangkan ditinjau dari kondisi kesejahteraannya jumlah anggota UPPKS yang menjadi peserta KB yang berasal dari pra sejahtera dan sejahteraI sebanyak 97.071 atau 83,41 \% dari jumalh PUS sebesar 116.373 peserta. Berdasarkan data tersebut terlihat bahwa peserta KB cendrung untuk terlibat dalam kegiatan UPPKS. Wilayah yang peserta UPPKS tertinggi ada di Kota Bekasi (100\%), sedangkan yang terendah di Kabupaten Bandung Barat (30,5\%), sementara untuk Propinsi Jawa Barat sebesar 61,1\%. Berdasarkan data tersebut terlihat bahwa terjadi ketimpangan dalam partispasi dalam kegiatan UPPKS antara satu kabupate/kota dengan kabupaten/kota lainnya. Hal ini menunjukkan pemberdayaan peremuan di setiap daerah sangat berbeda-beda tergantung kondisi dari masyarakat serta budaya yang berkembang di daerah tersebut.

\section{KESIMPULAN DAN SARAN Kesimpulan}

Berdasarkan kajian tersebut maka dapat ditarik kesimpulan sebagai berikut :

1. Partisipasi perempuan dalam program Keluarga Berencara sangat tinggi, akan tetapi itu tidak dapat dijadikan ukuran tentang keberdayaan perempuan dalam program Keluarga Berencana (KB). Hal ini disebabkan ada sebagian perempuan dalam menentukan partispasi dalam program Keluarga Berencana ditentukuan oleh pihak lain, khususnya laki-laki yang menjadi suaminya.

2. Partisipasi laki-laki dalam program Keluarga Berencana masih sangat rendah. Hal ini menunjukkan bahwa dominiasi lakilaki dalam menentukan partisipasi dalam program Keluarga Berencana masih tinggi.

3. Masih tingginya angka kelahiran dan kematian ibu dan bayi di Jawa Barat juga disinyalir karena perempuan masih rendah pengetahuannya serta masih belum pedulinya laki-laki terhadap kesehatan dan keselamatan ibu dan bayi.

4. Partisipasi perempuan dalam program pemberdayaan yang berhubungan dengan Keluarga Berencana untuk Propinsi Jawa Barat sudah tinggi. Akan tetapi tingginyan partisipasi itu juga tidak serta menunjukkan bahwa pembedayaan terhadap perempuan 
sudah bagus, hal ini disebabkan karena masih adanya keterpaksaan dalam partisipasi terebut. Selain itu juga belum meratanya partisipasi dalam program pemebredayaan antara satu daerah dengan daerah lainnya.

\section{Saran}

1. Masih perlunya sosialisasi dan peningkatan pengetahuan baik itu untuk laki-laki maupun perempuan mengani Keluarga Berencana (KB). Sosialisasi ini perlu dilakukan karena masih banyaknya masyarakat baik laki-laki maupun pengetahuan yang perlu ditingkatkan pengetahuan mengenai Keluarga Berencana (KB) sehingga pada akhirnya peserta Keluarga berencana (KB) bukan sebagai suatu keterpaksaan tetapi merupakan suatu kebutuhan.

2. Perlu dibuat kebijakan mengenai peserta Keluarga Berencana (KB) yang diperuntukkan bagi laki-laki. Sebagia contoh kebijakan bahwa lakia-laki yang sudah berumur tertentu harus menjadi peserta Keluarga Berencana, atau bagi Pegawai Negeri Sipil selain harus mempunyai anka dua orang juga harus lakilakinya menjadi peserta aktif Keluarga berencana $(\mathrm{KB})$.

3. Mendorong lebih banyak lagi perempuan untuk berpartiipasi dalam program pemberdayaan khususnya untuk akseptor dan PUS. Hal ini dapat dilakukan dengan mempermudah persyaratan untuk terlibat dalam program pemebrdayaan perempuan khususnya dalam meningkatkan kesejahteraan keluarga.

\section{DAFTAR PUSTAKA}

Agusta, I. 2007. Aneka Metode Partisipasi Untuk Pembangunan Desa. Blogspot.

Badan Pusat Statistik. (2007). Indikator Kunci Indonesia Edisi Tahun 2007. Jakarta: C.V. Dharma Putra

Badan Pusat Statistik. (2010). Data Strategis BPS. Jakarta: C.V. Nasional Indah

Cathart, R.S., and Larry A. Samovar, 1974. Small Group Communication : A Reader. New York : Holt, Rinehart and Winston, Inc.

Chamala, R.S., 1995. Overview of Participative Action Approaches in Australian

Darroch, R. K., Meyer, P. A., dan Singarimbun, Masri. (1981). Two are not enough: the values of children to Javanese and Sundanese. Honolulu: East-West Center

Data statistik kependudukan Indonesia, Majalah Tempo, Jakarta,Februari 2011.

Fawcett, J.T. (1984). Psikologi dan Kependudukan. Jakarta: C.V. Rajawali

Nasution, Anwar, KB Untuk Indonesia Lebih Baik, Rajawali Press, Semarang 1999.

Participative Approaches for Landcare: Perspective, Policies, Program.

Rahmat, Adi, SH, Ledakan Penduduk Ancam Indonesia, Pustaka Media, Jakarta 2000.

Sanusi, Ahmad, Sejarah Perkembangan KB di Indonesia, Mitra Media Press, Bandung 1998.

Savitri, R. I. (2011). Prospek Program Keluarga Berencana di Jawa Barat Sepuluh Tahun Mendatang. Depok: Universitas Indonesia.

Silalahi, Karlinawati., dan Meinarno, E. A. (2010). Keluarga Indonesia. Jakarta: Rajawali Press

Sensus Penduduk 2010, www.Bps.go.id 